\title{
Twice-daily cimetidine does not increase gastric bacterial flora
}

\author{
J. T. BOURNE* \\ B.Sc., M.D., M.R.C.P. \\ R. A. MOUNTFORD \\ M.D., M.R.C.P., F.R.C.R. \\ R. E. BARRY \\ B.Sc., M.D., F.R.C.P. \\ Department of Medicine, University of Bristol, Bristol Royal Infirmary, Bristol BS2 8HW
}

\begin{abstract}
Summary
Thirty patients with peptic ulcer (20 duodenal, 10 gastric) underwent glucose-hydrogen $\left(\mathrm{H}_{2}\right)$ breath tests before and after 6 weeks treatment with cimetidine, $\mathbf{4 0 0} \mathrm{mg}$ twice daily. For the group as a whole, basal breath $\mathrm{H}_{2}$ and integrated $\mathrm{H}_{2}$ output over a $2.5 \mathrm{hr}$ test period was unchanged by cimetidine treatment. We conclude that there was no evidence of significant gastric bacterial colonization following twice daily cimetidine treatment.
\end{abstract}

KEY WORDS: duodenal ulcer, gastric ulcer, nitrosamine.

\section{Introduction}

Production of nitrosamines following bacterial overgrowth in the hypochlorhydric stomach may be a mechanism for potential carcinogenesis in patients on long-term cimetidine (Editorial, 1981). The extent and significance of such bacterial overgrowth is controversial. There is little doubt that bacterial numbers increase in the context of raised intragastric pH immediately following ingestion of cimetidine (Deane et al., 1980; Ruddell et al., 1980; Muscroft et al., 1981a; Stockbrugger et al., 1981). Doubt has been raised whether such bacteria are metabolically active or persist long enough to be of importance (Muscroft et al., 1981b; Milton-Thompson et al., 1982).

We have sought to assess bacterial colonization in patients receiving cimetidine using an accepted functional assay (Levitt and Ingelfinger, 1968; Metz et al., 1976). Patients received twice daily cimetidine in a regime of proven efficacy (Kerr, 1981). Such regimes are likely to be adopted for patients receiving long-term treatment and who, in turn, are most at risk from potential carcinogenesis.

\section{Patients and methods}

Thirty patients (age range: $30-83$ years, mean: 60 ) with endoscopically proven peptic ulcers (20 duode-

\footnotetext{
*Present address: Department of Rheumatology, St Bartholomew's Hospital, London EC1A 7BE.
}

nal, 10 gastric) underwent a glucose-hydrogen $\left(\mathrm{H}_{2}\right)$ breath test before and after 6 weeks treatment with cimetidine, $400 \mathrm{mg}$ twice daily taken at 10.00 p.m. and $8.00 \mathrm{a} . \mathrm{m}$. No patient had received cimetidine or other histamine $\mathrm{H}_{2}$ receptor antagonists before the study and poorly compliant patients were excluded. Patients fasted from mid-night for the glucose- $\mathrm{H}_{2}$ breath test which commenced at 8.30 a.m. The morning dose of cimetidine was omitted. Four basal breath $\mathrm{H}_{2}$ estimates were made at 15 -min intervals using a Hoek Loos breath hydrogen analyser (Levitt and Ingelfinger, 1968). Fifty grams of glucose in 200 $\mathrm{ml}$ water was then administered by mouth. Breath $\mathrm{H}_{2}$ was estimated serially at 15 min intervals for $2.5 \mathrm{hr}$. Basal breath $\mathrm{H}_{2}$ and integrated $\mathrm{H}_{2}$ output with respect to time (indicated by the area under the curve) were measured as an index of bacterial metabolic activity before and after cimetidine treatment. Significance was assessed by means of a paired $t$-test.

\section{Results}

For the group as a whole basal breath $\mathrm{H}_{2}$ output was unchanged by cimetidine treatment (Table 1). Similarly no significant change was seen in the integrated $\mathrm{H}_{2}$ output over the test period. No evidence of significant bacterial colonization following cimetidine treatment was therefore demonstrated. Before treatment basal $\mathrm{H}_{2}$ levels in patients with duodenal ulcer (DU) were higher than in those with gastric ulcer (GU): DU $105 \pm 25.5 \mathrm{ppm}$, GU $58 \pm 5.9$ ppm: $(P<0.05)$. This difference was lost after cimetidine treatment.

\section{Discussion}

There is considerable evidence of an increased gastric flora as a consequence of raised intragastric $\mathrm{pH}$, immediately following cimetidine administration 
TABLE 1. Basal breath $\mathrm{H}_{2}$ and integrated $\mathrm{H}_{2}$ output (ppm) in 30 patients with duodenal (20) or gastric ulcer (10) before and after 6 weeks cimetidine $400 \mathrm{mg}$ twice daily. (A) All ulcers combined (B) Groups expressed separately

\begin{tabular}{lrrrrr}
\hline & \multicolumn{2}{c}{ Pre-treatment } & \multicolumn{2}{c}{ On cimetidine } \\
& Mean & S.E.M. & Mean & S.E.M. & $P$ \\
\hline (A) & & & & & \\
$\quad$ Basal breath $\mathrm{H}_{2}$ & 89.7 & 17.5 & 81.7 & 9.2 & NS \\
$\quad$ Integrated $\mathrm{H}_{2}$ output & 10.5 & 2.8 & 9.1 & 1.8 & $\mathrm{NS}$ \\
$\begin{array}{l}\text { (B) } \\
\quad \text { Basal breath } \mathrm{H}_{2}\end{array}$ & & & & & \\
$\quad \begin{array}{l}\text { Duodenal } \\
\text { Gastric }\end{array}$ & 105.0 & 25.5 & 78.0 & 8.6 & NS \\
$\quad$ Integrated $\mathrm{H}_{2}$ output & 58.0 & 5.9 & 88.0 & 22.4 & NS \\
$\quad$ Duodenal & 10.3 & 3.9 & 8.6 & 1.9 & NS \\
$\quad$ Gastric & 11.0 & 3.3 & 10.0 & 3.9 & NS \\
\hline
\end{tabular}

Basal breath $\mathrm{H}_{2}$ : duodenal vs gastric ulcer (a) pre-treatment $P<0.05$, (b) on cimetidine $P=0.318$ (NS); S.E.M. = standard error of mean; NS = not significant.

(Deane et al., 1980; Ruddell et al., 1980; Muscroft et al., 1981a; Stockbrügger et al., 1981). Important to any potential role in carcinogenesis is the metabolic activity of such bacteria and the length of time for which they maintain that activity in the stomach. For this reason we chose to study patients on a twice daily cimetidine regime which is of relevance where longterm maintenance therapy is contemplated. Patients were studied $10.5 \mathrm{hr}$ after their last (evening) cimetidine dose in preference to immediately after their morning dose. Muscroft et al. (1981a) showed that of 41 patients taking cimetidine, $400 \mathrm{mg}$ at night, $34 \%$ had significant bacteria in their aspirates 12-13 hr later, whilst Longstreth, Go and Malagelada (1976) found three out of six patients to be anacid 8 hr after a single $400 \mathrm{mg}$ cimetidine dose.

Hydrogen is not produced by human metabolic processes but is released by the activity of gut flora on a glucose substrate. Since glucose is completely absorbed in the upper gastrointestinal tract without contact with colonic or ileal flora, breath hydrogen analysis following an oral glucose load provides a simple means of detecting metabolically active bacteria in the stomach and upper gastrointestinal tract. In 30 patients given cimetidine, $400 \mathrm{mg}$ twice daily, no increase in bacterial activity was detected. Whilst the sensitivity of this technique has not been accurately established, it has nevertheless found an important place in clinical practice where evidence of upper gastrointestinal bacterial colonization has been sought (Metz et al., 1976). Not all types of gut bacteria are detected by this technique (Metz et al., 1976). However a very wide range of bacteria produce hydrogen during fermentation (Levitt and Ingelfinger, 1968). Our results make it unlikely that there is a large undetected reservoir of metabolically active nitrate-reducing bacteria in the upper gastrointestinal tract of these patients (Reed et al., 1981).

The finding of high basal $\mathrm{H}_{2}$ levels in untreated
DU patients compared with GU patients was unexpected. Muscroft et al. (1981a) analysed gastric aspirates from 51 untreated DU patients and found $88 \%$ to be sterile. Only two aspirates contained more than $10^{6}$ organisms $/ \mathrm{ml}$. It is likely that elevated basal hydrogen was due to fermentation of carbohydrate in the colon (Levitt and Ingelfinger, 1968). An alternative explanation is that relief of pyloric oedema and improved gastric emptying resulted in diminished $\mathrm{H}_{2}$ production in these patients following treatment.

Additional data are clearly required concerning the metabolic activity and carcinogenic potential of bacteria and their products in patients receiving cimetidine. Nevertheless, this study provides some assurance that such bacterial colonization does not appear to be prolonged or important in patients on maintenance regimes of this type.

\section{Acknowledgments}

We are grateful to Mrs R. Pratt for carrying out the glucose- $\mathrm{H}_{2}$ breath tests.

\section{References}

Deane, S.A., Youngs, D.J., Poxon, V.A. \& Keighley, M.R.B. (1980) Cimetidine and gastric microflora. British Journal of Surgery, 67, 371 (abstr).

EDITORIAL (1981) Bacteria in the stomach. Lancet, ii, 906.

KERR, G.D. (1981) Cimetidine: twice daily administration in duodenal ulcer-results of $\mathrm{UK}$ and Ireland multicentre study. In: Cimetidine in the 80's. (Ed. J. H. Baron), p. 9. Churchill Livingstone, London.

LEVITT, M.D. \& INGELFINGER, F.J. (1968) Hydrogen and methane production in man. Annals of the New York Academy of Sciences, $150,75$.

LoNGstreth, G.F., Go, V.L.W. \& Malagelada, J.R. (1976) Cimetidine suppression of nocturnal gastric secretion in active duodenal ulcer. New England Journal of Medicine, 294, 801.

Metz, G., Gassull, M.A., Drasar, B.S., Jenkins, D.J.A. \& BLENDIS, L.M. (1976) Breath hydrogen test for small-intestinal bacterial colonization. Lancet, i, 668 .

Milton-ThompSon, G.J., Lightfoot, N.F., AhMEt, Z., Hunt, 
R.H., Barnard, J., BaVIN, P.M.G., BRimblecombe, R.W., DARKIN, D.W., MOORE, P.J. \& VINEY, N. (1982) Intragastric acidity, bacteria, nitrite and $\mathrm{N}$-nitroso compounds before, during and after cimetidine treatment. Lancet, i, 1091.

MusCroft, T.J., Youngs, D., Burdon, D.W. \& KeIGHLeY, M.R.B. (1981a) Cimetidine and the potential risk of post-operative sepsis. British Journal of Surgery, 68, 557.

MuSCROFT, T.J., YoungS, D.J., BURdon, D.W. \& Keighley, M.R.B. (1981b) Cimetidine is unlikely to increase formation of intragastric $\mathrm{N}$-nitroso compounds in patients taking a normal diet. Lancet, i, 408.

Reed, P.I., Smith, P.L.R., Haines, K., House, F.R. \& Walters,
C.L. (1981) Gastric juice N-nitrosamines in health and gastroduodenal disease. Lancet, ii, 550.

RudDell, W.S.J., AXoN, A.T.R., Findley, J.M., BARTHOLOMEW, B.A. \& HiLL, M.J. (1980) Effect of cimetidine on the gastric bacterial flora. Lancet, i, 672 .

StockbrügGer, R.W., Eugenides, N., BARTHOLOMEW, B., WAL TERS, C.L., ThOMPSON, R.E.M., Hill, M.J. \& CotTon, P.B. (1981) Cimetidine-treatment intragastric bacterial overgrowth and its consequences. Gastroenterology, 80, 1295, (abstr).

(Accepted 13 December 1983) 